\title{
Minireview
}

\section{Setting the Tempo in Land Remediation: Short-Term and Long-Term Patterns in Biodiversity Recovery}

\author{
SINA M. ADL ${ }^{1 *}$ \\ ${ }^{1}$ Department of Biology, Dalhousie University, 1355 Oxford St. Halifax, NS. B3H 4J1 Canada
}

(Received January 10, 2008—Accepted January 30, 2008)

Land to be remediated, such as those affected by heavy metals or organic pollutants, can be remediated using biological approaches. These include, quarries and strip mines, or land impacted by oil pollution or other organic pollutants. Phytoremediation is usually a key component of bioremediation. However, without restoring soil organic matter, the soil biodiversity takes decades to recover. The soil organisms are a key component of soil function, and support plant growth. In addition, the soil microbiology is essential both for bioremediation and supporting phytoremediation. Using inexpensive sources of quality organic matter, it should be possible to accelerate recovery of ecosystem health and biodiversity. One potential source of untapped organic matter is municipal solid waste as a composted amendment. The organic matter amendment promotes soil structure and the creation of adequate habitat and substrate for the soil decomposition food web. Long-term chronosequence studies indicate that soil food webs tend to make a transition after about 20 years to a stable community structure. This approach could be used to gain carbon credits by restoring degraded or polluted soils.

Key words: carbon credits, compost, soil organic matter, soil reclamation, species succession

\section{Introduction}

Vast land areas of the planet have been categorized as degraded or unstable soils in need of remediation. These include a global assessment of soil degradation study ${ }^{47)}$, or various official websites providing maps of the extent of soil degradation, for example UNEP GRID-Arendl at www.grida.no/db/maps/prod/level3/id_1238.htm (accessed $08 / 01 / 2008$ ). In addition, there are many local sites in need of remediation, such as opencast (strip) mine sites, quarries, areas degraded by vehicle traffic or construction, areas damaged by uncontrolled recreation, or polluted sites ${ }^{29)}$. It should be possible to combine both the prospect of obtaining carbon credits to mitigate global warming, with remediation of soils $^{37)}$. Sites that have been disturbed by mining or pollution are ideal for organic amendment, coupled to bioremediation, to reduce site pollution and toxicity. In addition, these sites could be accelerated towards a healthy ecosystem by the organic matter amendment and bioremediation.

The desired outcome of land remediation is normally to recover a soil that can support a healthy ecosystem. In contrast to chemical or physical approaches ${ }^{44)}$, new trends are more biological and include restoration of top soil. One attraction of biological approaches, where it is feasible, is that it can be cheaper than the chemical and physical approaches ${ }^{10,23,56)}$. Not all sites can be remediated without prior chemical processing. However, biological restoration is often a required final step in approving remediated sites. Unfortunately, the effectiveness of most chemico-physical techniques have not been verified in the field ${ }^{10)}$, and moreover, the land is left infertile as the soil life is destroyed in

\footnotetext{
* Corresponding author. E-mail: sadl@dal.ca; Tel: 902-494-2753; Fax: 902-494-3736.
}

the process. Therefore, improvements in bioremediation techniques, especially on-site and in-situ approaches that restore soil fertility and the soil organisms responsible for nutrient cycling through decomposition, promise to be profitable and beneficial. Phytoremediation is usually a central component of bioremediation. It involves promoting growth of plant species that are good colonizers and can tolerate heavy metals, pollutants, low organic matter, and generally a less desirable habitat. Another component of bioremediation is to promote the recovery of soil structure through organic matter amendment. The recovery of soil structure through mineral-organic matter aggregate formation, each called a ped, provides habitats for the soil biota. Recovery of the soil biology is essential for organic matter recycling into dissolved nutrients. One key research question that remains to be addressed is, how long does biodiversity require to recover a stable, resilient community structure? This paper provides a brief review of research that emphasizes the need for soil biodiversity recovery, and its dynamics over the short-term and through decades in the long-term. The main thesis developed is that soil organic matter development is key to the rehabilitation of soil, and that the time scale for soil recovery depends on the rate of habitat creation as ped structure recovers.

\section{Phytoremediation}

Heavy metals are the main inorganic soil contaminants to be remediated ${ }^{5}$. Phytoremediation is a promising method of remediation in soils of low to moderate heavy metal contamination $^{34)}$. About 400 species of plants can be used to remove, transfer, stabilize, degrade heavy metals in soil ${ }^{35}$. The processes were defined into categories as phyto-accumulation, phytodegradation, phytostabilization, rhizofiltration, 
or enhanced biodegradation ${ }^{13)}$. These plants tend to form shallow roots that spread horizontally, and do not penetrate well. Heavy metals tend to accumulate in the cells ${ }^{57,68)}$, or become stabilized with root derived chelating agents ${ }^{43,73)}$. In many plants, heavy metal accumulation, sequestration or stabilization is mediated by mycorrhizae that protect fine roots from excessive heavy metal concentrations ${ }^{34)}$.

Organic soil pollution, usually by chemical spills or oil pollution, can also be treated by phytoremediation ${ }^{23)}$. The mechanisms include root uptake followed by transfer to other tissues. The mechanism is aided by mycorrhizae and rhizodeposition, as for heavy metals. There are numerous other interactions between roots and soil microorganisms that are being reported, that co-stimulate the rhizosphere organisms and root growth through hormones and growth factors ${ }^{8,9,25,41)}$. Thus any phytoremediation effort also needs to consider the parameters required to promote mycorrhizal fungi, and other root-soil organism interactions.

Phytoremediation with suitable plant species can also be an effective way of returning key environmental parameters, that will enhance recovery of the soil fertility and the ecosystem health. Plants provide shade to reduce surface temperature, and root water-uptake reduces leaching. Rhizodeposition, in the form of root exudates, is an important source of labile nutrients that promotes the activity of decomposers in the rhizosphere ${ }^{41,47,73)}$, thus enhancing the availability of dissolved nutrients from decomposition. Rhizodeposition also promotes soil structure and formation of peds (soil aggregates) that create microhabitats for microorganisms indirectly, through promotion of biological activity ${ }^{15}$. Leaf litter accumulation and coarse woody debris contribute to the formation of a thin organic horizon. The gradual accumulation of an organic soil layer further enhances moisture retention and modulates temperature fluctuations. These changes begin to recreate the soil habitat for the biodiversity that is required for decomposition. The time period for plant growth and accumulation of a thin organic horizon takes several years, even with fast growing species. The gradual increase in soil organism species number (or species richness) in soil organic matter is a first step towards the recovery of a food web. The rate-limiting step in phytoremediation, for plant growth and survival on a site under restoration or reclamation, is whether the soil solution can provide sufficient nutrients to plants without being toxic to fine roots ${ }^{25}$.

\section{Bioremediation}

Success of ecological restoration by traditional botanical measures alone (such as diversity, biomass, and density of plant species) does not correspond with, or indicate, successful establishment of soil biodiversity. Indeed, the botanical measures are of little value to monitor soil function and will not account for subsequent plant survival failure if the soil biology does not recover ${ }^{33,77)}$. Recovery of soil species, especially mycorrhizae, and thus soil function is important because they will tend to incorporate organic and inorganic pollutants in cells, thus reducing the amount that is accessible to roots ${ }^{27,31,34)}$. As these molecules accumulate in fecal pellets, cell walls, skeletal polymers and tissues, this organic matter contributes to sequestration of toxins or

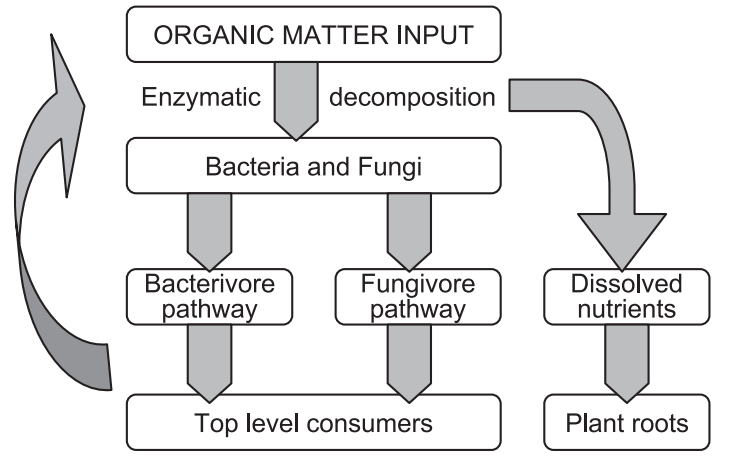

Fig. 1. The soil food web is responsible for decomposition of the organic matter. The functional categories consist of many species, each with different substrate or prey preferences and seasonal preferences. Undigested and excreted organic matter contributes to soil structure and dissolved nutrients.

pollutants ${ }^{22,27)}$. In addition, digestion by bacterial extracellular enzymes, detoxifies many organic compounds ${ }^{40)}$. Other soil organisms, such as the protists and fungi may also contribute to some detoxification of organic pollutants ${ }^{58,59,60,79)}$, as well as micro-invertebrates and earthworms ${ }^{27,42)}$. Detoxification occurs by removing an inhibitory side-group of organic molecules or by opening a chemical bond, thus permitting further metabolism of the molecule. These modified detoxified compounds can then be substrates for growth used by other species. Alternatively, they accumulate and contribute to soil organic matter. In addition, root derived secondary metabolites can stimulate the biodegradation of organic pollutants by bacteria ${ }^{64)}$.

According to ecological theory ${ }^{18,19)}$, in order to develop a functioning decomposer food web, that can promote detoxification and site remediation, several factors need to be considered. First, the soil toxicity needs to be reduced sufficiently to support eukaryotes as well as prokaryotes. The functional groups, or ecological guilds, all need to be present, but they each need to contain a diversity of species. The increased species richness in each functional group is believed to enhance stability and productivity of the food $w_{e} b^{19)}$. Over time, with ecological succession, the species in each functional group change. The early colonizers tend to be opportunists that prefer more easily digested labile substrates. With time, as the food web matures, there is an increase in the number of species that grow slowly on more difficult substrates, which is reflected in an increase in fungivorous and omnivorous species ${ }^{18,33,62)}$. For example, an enhanced fungi-fungivore pathway is usually a good indicator of a stable environment and a recovering food web; in contrast disturbed sites, or agricultural sites, tend to be largely dominated by bacteria and bacterivores ${ }^{20,71,74)}$ (Figure $1)$.

\section{Biodegradation}

Soil organisms are responsible for the decomposition of organic matter, into mineralized or soluble forms that become plant root available. In the process, they also digest organic pollutants into non-toxic substrates (biodegradation), and contribute to the sequestration or stabilization of toxic 
Table 1. Sources of organic matter and nitrogen compounds into soil compiled from knowledge of the biology of different organisms ${ }^{2}$

\begin{tabular}{|c|c|c|}
\hline Substrate & Source & Main nutrient \\
\hline $\mathrm{NH}_{4}$ & Eukaryote waste by-product & Soluble ${ }^{a} \mathrm{~N}_{\text {inorg }}$ \\
\hline Urea & Soil animal waste by-product & Soluble ${ }^{b} \mathrm{~N}_{\text {org }}$ \\
\hline Uric acid & Birds and earthworms waste by-product & Insoluble $\mathrm{N}_{\text {org }}$ \\
\hline Guanine crystals & Mites waste by-product & Insoluble $\mathrm{N}_{\text {org }},{ }^{\mathrm{c}} \mathrm{C}_{\text {org }}$ \\
\hline Nitrate & Cell lysis & Soluble $\mathrm{N}_{\text {inorg }}$ \\
\hline Nitrite & Cells lysis & Soluble $\mathrm{N}_{\text {inorg }}$ \\
\hline Amino acids and proteins & Cells and tissues & Variably soluble $\mathrm{N}_{\text {org }}, \mathrm{C}_{\text {org }}$ \\
\hline Nucleotides and nucleic acids & Cells and tissues & Soluble $\mathrm{N}_{\text {org }}, \mathrm{C}_{\text {org }}$ \\
\hline $\mathrm{N}$-acetyl glucose and chitin & Fungi cell walls, invertebrate exoskeleton & Soluble monomer, $\mathrm{N}_{\text {org }}, \mathrm{C}_{\text {org }}$ \\
\hline Glucose and cellulose & Plant cell wall & Soluble monomer, $\mathrm{C}_{\text {org }}$ \\
\hline Other sugars and carbohydrates & Cells, tissues, plant cell wall & Soluble monomer, $\mathrm{C}_{\text {org }}$ \\
\hline Lipids and sterols & Cell lysis & Hydrophobic, $\mathrm{C}_{\mathrm{org}}$ \\
\hline
\end{tabular}

${ }^{\mathrm{a}} \mathrm{N}_{\text {inorg }}$ inorganic nitrogen; ${ }^{b} \mathrm{~N}_{\text {org }}$ organic nitrogen; ${ }^{\mathrm{c}} \mathrm{C}_{\text {org }}$ organic carbon.

molecules such as heavy metals ${ }^{22,27)}$. Several recent text books have provided reviews with perspectives on soil zoology $^{16,39)}$, soil biochemistry ${ }^{11,51)}$, and soil ecology $y^{2,6)}$. The emphasis in understanding soils has gradually shifted towards its biological and ecological role in maintaining the integrity of ecosystems. Simply phrased, the organic matter in the top soil is digested enzymatically by microorganisms into soluble components in the soil solution. The nutrients and dissolved minerals in this solution are root available. The microorganisms themselves are consumed by larger species that include protists, nematodes, micro-arthropods, enchytraeids and earthworms ${ }^{2}$. The food web is responsible for the recycling of the organic matter, through decomposition, by returning the dissolved nutrients to plant roots, and by returning carbon dioxide released from respiration of soil organisms to plants for photosynthesis (Figure 1).

Recovery of the soil ecology is also essential for making nitrogen available to plants naturally. The soil organic matter is poor in nitrogen, consisting mostly of plant cell wall carbohydrates, such as cellulose, hemicelluloses and xylans ${ }^{2,51)}$. The biological pathway for nitrogen to enter the soil food web is through nitrogen fixation by free-living bacteria ${ }^{67)}$. Some plants, the legumes, harbor symbiotic nitrogen fixing bacteria in root nodules. Other pioneer plants that grow in abandoned mine or dredge spoil such as alders (Alnus) form a symbiotic association with a filamentous nitrogen fixing bacteria genus, Frankia. As bacteria are consumed by the soil food web species, the nitrogen in the cells is passed on through the system. Organic molecules with nitrogen occur mostly as chitin from fungal cell walls and from invertebrate cuticles; a smaller amount of more labile nitrogen containing molecules are released in the form of nucleic acids and proteins $^{2,51)}$. These are mineralized through decomposition. Inorganic nitrogen also enters the soil solution from excreted wastes of the soil species. This decomposition food web is the main route of transferring the nitrogen fixed in bacteria to the soil solution for root uptake and plant metabolism. A further source of labile nitrogen molecules into soil is from root exudates $^{25,47)}$.

The accumulation of organic matter in the soil comes from plant tissues and from the soil food web species (Table 1). The plant tissues include senesced roots, root exudates, pollen and other plant tissues such as leaves and stems. The soil organisms decompose the organic matter and returns the unassimilated portion in the form of excreted waste pellets of incompletely digested material. These fecal pellets in turn become a habitat and substrate for further decomposition by species $^{2,14,52)}$. However, as the organic matter is digested and recycled, the more labile molecules are used and the recalcitrant molecules accumulate. The accumulation of the recalcitrant molecules contributes to the accumulation of organic matter and soil structure ${ }^{26)}$. In biological terms, the recalcitrant substrate molecules contain chemical bonds that are energetically more costly to digest. In other words, the ratio of synthesis of cellular ATP from substrate metabolism, compared to the input of ATP required to break substrate chemical bonds, is small.

\section{Ped formation}

A key step in promoting a soil food web with stable and complete community structure is the creation of appropriate habitats for all these species. The biologists tend to think of this habitat as peds (Figure 2). A ped is a natural aggregate of soil minerals held together by organic matter. Root exudates, fungal mycelia, bacterial capsules and other mucopolysaccharides contribute to holding peds together. Ped composition affect soil aggregate stability, bulk density and tortuosity. Development of peds, and thus soil structure, depends on

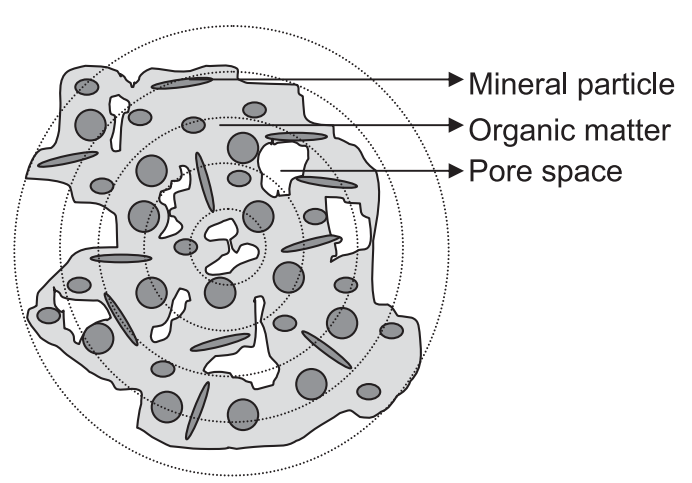

Fig. 2. The structure of a ped provides a diversity of habitats that sustain the diversity of species required to maintain a stable community structure. Towards the centre of the ped, the spaces become increasing anaerobic, along contour lines. 
the accumulation of organic matter that binds the mineral particles together ${ }^{65)}$. Each ped provides a range of sizes, with more or less aggregate stability ${ }^{69)}$. Peds provide a gradient of aerobic to anaerobic pore spaces that permit a diversity of bacteria metabolic pathways. The space between peds and pores within peds become the habitats, or the habitable pore spaces, for the other species. Therefore, in recreating habitable pore spaces to sustain the soil biology, two questions must be addressed. First, how to recreate peds in sites to be remediated; and second, how long does it take to recover sufficient biodiversity for a functioning and stable community structure?

In order to expedite the process, the most common approaches are to amend the site with organic matter. The organic matter or top soil can be mixed into the existing mineral soil by ploughing or other techniques. There are several common sources of organic matter that are used, as discussed below. The first is storing the top-soil from the site for re-use during remediation. The second is to obtain a fresh source of top soil or organic matter from another location. The third is to use recycled organic wastes or composted products.

\section{Site remediation}

The easiest organic matter amendment method is to use top soil from the same site, set-aside early before the site is disturbed $^{30,32,54,61,76)}$. The top soil is normally kept in heaps nearby for spreading during site restoration. The disadvantages of this method are twofold. First, soil compaction during storage needs to be alleviated mechanically, and it may require to be ploughed back into the soil ${ }^{54,61)}$. Second, with extended storage, the quality of the organic matter decreases, as it is decomposed without replenishment. This alters the soil community and will reduce its effectiveness as a biological inoculum during remediation, especially after several years of storage ${ }^{30)}$. Furthermore, leaching from the piled soil reduces its fertility when it is to be applied again during remediation. However, there can be cost advantages to saving the top soil with its organic matter. In addition, relying on the top-soil from the same site avoids having to dig-up top soil from an other site, thus causing a second environmental disturbance elsewhere.

The second method is to locate a source of fresh top soil with organic matter from an approved location ${ }^{72}$. The main advantage of this approach is that the amendment contains both labile and recalcitrant organic matter, as well as the soil organisms. In some places this can be difficult due to local legislation or a scarcity of accessible top soil. If peat mining is an option, this provides a rich and suitable source of organic matter for remediation. The disadvantages of this method are that legislated environmental standards set limits to the accessibility and availability of top soil or peat. In some cases, this may create a second site in need of remediation, which adds to the cost of land restoration.

The third method is to apply composted organic matter $^{29,46)}$. The advantage of this approach is that there is no shortage of agricultural or urban organic waste to compost. In addition, composts are rich in both labile and more recalcitrant compounds, with adequate concentrations of nitrogen and other nutrients. Composts can sequester both organic and inorganic pollutants, improve bulk density and structure, reduce leaching losses of nutrients, and provide a rich top soil immediately ${ }^{29}$. Moreover, they promote recycling of wastes into products and can be viewed as an additional environmental benefit. The main disadvantage of this method is that the infrastructure to accumulate the organic wastes, sort the material, manage the compost piles, and store the product, are not always in place. In some municipalities, there may already be composting facilities that can handle the process. In other situations, compost production may have to be budgeted into the remediation protocol. However, the facility will continue to be useful beyond its use during site remediation and can remain as a benefit to the community. Furthermore, for purposes of site remediation and restoration, the quality of the compost does not need to match that for agricultural uses. Therefore sources of compost that tend to be more difficult to commercialize, and cheaper, would be more than adequate for bioremediation. These include municipal solid waste and sewage sludge that tend to have elevated heavy metal concentrations, paper pulp mill organic wastes, nauseous agricultural or agribusiness organic by-products. As many sites for remediation tend to be already high in heavy metals, levels in municipal solid waste or sewage sludge compost will not affect the site ${ }^{29)}$. In fact, sequestration into the organic matter will reduce site bioavailability of heavy metal levels, and their leaching into the surrounding area. In sites affected by organic pollutants, amendment with organic matter would have the dual role of diluting the pollutant, thus reducing toxicity, and sequestering the pollutant.

Combinations of these approaches may be suitable. In particular, combining the top-soil storage method with composted amendment would restore the quality and fertility of the stored soil, as well as providing a source of uncontaminated mineral soil to mix into the compost. These biological approaches have an additional benefit that will only increase in the future ${ }^{34,38)}$. Adding soil organic matter to mineral soil is a form of carbon sequestration (or carbon sink) similar to the purchase of agriculture carbon sequestration services, used to mitigate green house gas emissions ${ }^{38,45)}$. Many national programs offer options to enter the carbon trading program and increase carbon credits. This can be an advantage to companies engaged in bioremediation as well as in promoting broader environmental benefits.

\section{Bioindicators}

Site recovery of species diversity and community structure during bioremediation can be monitored through standard procedures ${ }^{12,58)}$. Indeed, an important factor in understanding soil ecology and its regulation of nutrient cycling through decomposition has been the standardization of soil biological methods over the past 15 years ${ }^{12,50)}$. This allowed more reliable comparisons between studies. The introduction of molecular biological tools to environmental assays further enhanced the quality of the monitoring and the resolution of the analysis ${ }^{24,53)}$. Overall, this molecular information can be used to monitor the recovery of bioindicator species, and of bioindicator system properties (Table 2). The measurements provide quantitative data for the statistical analysis of species richness (biodiversity indices), of functional ecology, of 
Table 2. Bioindicators and purpose in environmental monitoring ${ }^{50)}$

\begin{tabular}{ll}
\hline \multicolumn{1}{c}{ Bioindicator } & Purpose \\
\hline Enzyme assays & Activity of specific enzyme functions (phosphatase, dehydrogenase, etc.) \\
DNA Differential Gradient Gel Electrophoresis & Bacteria, protist and fungi species richness, community structure \\
Nematodes & Community structure, site maturity index \\
Micro-arthropods & Community structure, food web complexity \\
Testate amoebae & Site recovery from disturbance \\
Ciliates & Site recovery from disturbance \\
Cercomonads & Site recovery from disturbance \\
Enchytraeids & Soil organic matter and profile development \\
\hline
\end{tabular}

community structure interaction stability, of community structure maturity index, and for other statistical methods used in ecology $y^{7,27,36,42)}$. There are two sets of data that are required for interpretation of biodiversity monitoring. First is to appreciate the dynamics of species abundances on the short term (weeks to years). Second is to determine the rate of successional change in species composition and community structure development over several years.

\section{Short-term dynamics}

Short-term fluctuations in the abundance of individuals of different species include changes in abundance over hours to months caused by reproduction, which can be seasonal in soil invertebrates, or weather related changes in temperature and moisture. Bacteria and protists tend to reproduce in hours to days, and respond quickly to changes in temperature and moisture or food availability ${ }^{3}$. The abundance changes can be of two orders of magnitude, as a combination of cell division and excystment. Invertebrates tend to reproduce over several weeks, or months, completing only one or more reproduction cycles each year ${ }^{2}$. The magnitude of these short term abundance changes need to be determined. Otherwise it is not possible to determine from one or two sampling times whether the site was sampled at a time when abundances were high (or low) due to weather or seasonal physical parameters. Short-term dynamics caused by seasonal effects on reproduction, or weather related day-to-day fluctuations can confound year to year comparisons based on 1-2 time points. Often these short-term dynamics in abundances confuse the data and prevent statistically supported conclusions (see for example $\left.{ }^{1,4,49}\right)$. For this reason ecologists prefer enumeration of the biodiversity at several time points, preferably spread across several years, instead of abundance studies.

\section{Long-term biodiversity recovery}

A useful approach in ecology to gather long-term data without waiting for decades is to carry out chronosequence studies $^{55}$. A review of chronosequence studies show that recovery of the soil organic matter improves soil structure, as peds form and the depth profile develops into horizons ${ }^{53,63}$. As peds form, in part with contributions from root exudates and litter input, there are increases in abundance and species richness that lead to a more resilient soil ecology $1,4,14,17,21,49,63,66)$. In many chronosequence studies that span several decades, and that compared stages of soil recovery from a disturbance, there is a transition in community structure that occurs $4,14,28,33,63,69,75,78)$. The transition is from a bacteria-bacterivory dominated food web with low food web stability, dominated by opportunists and early colonizers, to a more stable and complex community with an enhanced fungi-fungivory component of the food web. Even though there is rapid colonization of soil after the disturbance, there is little change in the soil ecology for many years. In these studies, the shift in community structure was not observed after 5 years, but was observed within 25 years into regeneration. Studies with time-samples between 5 and 25 years of recovery showed indications of change in the food web. However, these studies also showed that soil communities continue to mature for about one century, when compared to undisturbed sites. If sites under remediation ${ }^{21,66)}$ can be amended with organic matter to support plant growth and a rudimentary soil ecology, then one should expect similar patterns in land remediation and reclamation to occur at an accelerated pace compared to unamended sites.

\section{Acknowledgements}

The author thanks K. Minamisawa and S. Shimano for the opportunity to write this review.

\section{References}

1) Addison, J.A., J.A. Trofymow, and V.G. Marshall. 2003. Abundance, species diversity, and community structure of Collembola in successional coastal temperate forests on Vancouver Island, Canada. Appl. Soil Ecol. 24:233-246.

2) Adl, M.S. 2003. The Ecology of Soil Decomposition. CAB International, Wallingford.

3) Adl, M.S., and D.C. Coleman. 2005. Dynamics of soil protozoa using a direct count method. Biol. Fertil. Soils 42:168-171.

4) Adl, M.S., D.C. Coleman, and F. Read. 2005. Slow recovery of soil biodiversity in sandy loam soils of Georgia after 25 years of no-tillage management. Agric. Ecosyst. Environ. 114:323-334.

5) Alloway, B.J. 1990. Soil processes and behaviour of metals. In B.J. Alloway (ed.), Heavy Metals in Soils Blackie, Glasgow.

6) Bardgett, R.D., M.B. Usher, and D.W. Hopkins. 2005. Biological Diversity and Function in Soils. Cambridge University Press, Cambridge.

7) Bongers, T., and M. Bongers. 1998. Functional diversity of nematodes. Appl. Soil Ecol. 10:239-251.

8) Bonkowski, M. 2004. Soil protozoa and plant growth-the microbial loop in soil revisited. New Phytol. 162:617-631.

9) Bonkowski, M., and F. Brandt. 2002. Do soil protozoa enhance plant growth by hormonal effects? Soil Biol. Biochem. 34:1709-1715.

10) Burns, R.G., S. Rogers, and I. McGhee. 1996. Remediation of inorganics and organics in industrial and urban contaminated soils, p. 361-410. In R. Naidu, R.S. Kookana, D.P. Oliver, S. Rogers, and M.J McLaughlin (ed.), Contaminants and the Soil Environment in the Australia Pacific Region. Kluwer Academic Publishers, London.

11) Cadish, G., and K.E. Giller. 1997. Driven by Nature: Plant Residue 
Quality and Decomposition. CAB International, Wallingford.

12) Carter, M.R., and E.G. Gregorich. 2007. Soil Sampling and Methods of Analysis. CRC Press, Boca Raton, Fl.

13) Chaudhry, T.M., W.J. Hayes, A.G. Khan, and C.S. Khoo. 1998. Phytoremediation: focusing on accumulator plants that remediate metal contaminated soils. Australas. J. Ecotoxicol. 4:3-51.

14) Chauvat, M., J.F. Ponge, and V. Wolters. 2007. Humus structure during a spruce forest rotation: quantitative changes and relationship to soil biota. Eur. J. Soil Sci. 58:625-631.

15) Chotte, J.L. 2005. Importance of soil microorganisms for soil aggregation, p. 107-122. In F. Buscot, and A. Varma (ed.) Microorganisms in soils: roles in genesis and functions. Springer, Berlin.

16) Coleman, D.C., D.A. Crossley, and P.F. Hendrix. 2004. Fundamentals of Soil Ecology, 2nd edn. Elsevier, New York.

17) Coleman, D.C., M.S. Adl, F. Reed, and S. Lachnicht. 2002. Ecological processes in eroded soils under conventional and conservation tillage. Proceedings 17th World Congress Soil Science, Thailand 90:18 .

18) De Ruiter, P.C., B. Griffiths, and J.C. Moore. 2002. Biodiversity and stability in soil ecosystems: patterns, processes and the effect of disturbance, p. 102-113. In M. Loreau, S. Naeem, and P. Inchausti (ed.), Biodiversity and Ecosystem Functioning-Synthesis and Perspectives. Oxford University Press, Oxford.

19) De Ruiter, P.C., A-M. Neutel, and J. Moore. 2005. The balance between productivity and food web structure in soil ecosytems, p. 139-153. In R.D. Bardgett, M.B. Usher, and D.W. Hopkins (ed.) Biological Diversity and Function in Soils. Cambridge University Press, Cambridge.

20) Donnison, L.M., G.S. Griffith, J. Hedger, P.J. Hobbs, and R.D. Bardgett. 2000. Management influences on soil microbial communities and their function in botanically diverse haymeadows of northern England and Wales. Soil Biol. Biochem. 32:253-263.

21) Frouz, J., and A. Nováková. 2005. Development of soil microbial properties in topsoil layer during spontaneous succession in heaps after brown coal mining in relation to humus microstructure development. Geoderma 129:54-64.

22) Gadd, G.F. 2005. Microorganisms in toxic-metal polluted soils, p. 325-358. In F. Buscot, and A. Varma (ed.), Microorganisms in Soils: Roles in Genesis and Functions. Springer, Berlin.

23) Gao, Y-z., and L-z. Zhu. 2003. Phytoremediation and its models for organic contaminated soils. J. Environ. Sci. 15:302-310.

24) Grayston, S.J., C.D. Campbell, R.D. Bardgett, J.L. Mawdsley, C.D. Clegg, K. Ritz, B.S. Griffiths, J.S. Rodwell, S.J. Edwards, W.J. Davies, D.J. Elston, and P. Millard. 2004. Assessing shifts in microbial community structure across a range of grasslands of differing management intensity using CLPP, PLFA and community DNA techniques. Appl. Soil Ecol. 25:63-84.

25) Gregory, P.J. 2006. Roots, rhizosphere and soil: the route to a better understanding of soil science? Eur. J. Soil Sci. 57:2-12.

26) Guggenberger, G. 2005. Humification and mineralizatin in soils, p. 85-106. In F. Buscot, and A. Varma (ed.), Microorganisms in Soils: Roles in Genesis and Functions. Springer, Berlin.

27) Haimi, J. 2000. Decomposer animals and bioremediation of soils. Environ. Pollut. 107:233-238.

28) Hánêl, L. 1996. Soil nematodes in five spruce forests of the Beskydy Mountains, Czech Republic. Fundam. Appl. Nematol. 19:15-24.

29) Hargreaves, J.C., M.S. Adl, and P. Warman. 2008. A review of the use of composted municipal solid waste in agriculture. Agric. Ecosyst. Environ. 123:1-14.

30) Harris, J.A., P. Birch, and K.C. Short. 1993. The impact of storage of soils during opencast mining on the microbial community: a strategist theory interpretation. Restor. Ecol. 1:88-100.

31) Harris, J.A., P. Grogan, and R.J. Hobbs. 2005. Restoration ecology and the role of soil biodiversity. In R.D. Bardgett, M.B. Usher, and D.W. Hopkins (ed.), Biological Diversity and Function in Soils. Cambridge University Press, Cambridge.

32) Holmes, P.M. 2001. Shrubland restoration following woody alien invasion and mining: effects of topsoil depth, seed source, and fertilizer addition. Restor. Ecol. 9:71-85.

33) Kardol, P., T.M. Bezemer, A. van der Wal, and W.H. van der Putten. 2005. Successional trajectories of soil nematode and plant communities in a chronosequence of ex-arable lands. Biol. Conserv. 126:317327.

34) Khan, A.G., C. Kuek, T.M. Chaudhry, C.S. Khoo, and W.J. Hayes.
2000. Role of plants, mycorrhizae and phytochelators in heavy metal contaminated land remediation. Chemosphere 41:197-207.

35) Kramer, U., R.D. Smith, W.W. Wenzel, I. Raskin, and D.E. Salt. 1997. The role of metal transport and tolerance in nickel hyperaccumulation by Thelapsi geosingense Halacsy. Plant Physiol. 115:16411650.

36) Krebs, C.J. 2000. Ecological Methodology, 2nd edn. Benjamin-Cummings, New York.

37) Lal, R. 2007. Soil Science and the carbon civilization. Soil Sci. Soc. Am. J. 71:14-37.

38) Lal, R., F. Follett, B.A. Stewart, and J.M. Kimble. 2007. Soil carbon sequestration to mitigate climate change and advance food security. Soil Sci. 172:943-956.

39) Lavelle, P., and A.V. Spain. 2002. Soil Ecology. Kluwer, Dordrecht.

40) Lengeler, J.W., G. Drews, and H.G. Schlegel. 1999. Biology of the Prokaryotes. Blackwell Science, New York.

41) Lin, C., S.M. Owen, and J. Penuelas. 2007. Volatile organic compounds in the roots and rhizosphere of Pinus spp. Soil Biol. Biochem. 31:951-960.

42) Majer, J. 1989. Animals in Primary Succession: the Role of Fauna in Reclaimed Lands. Cambridge University Press, Cambridge.

43) Marschener, H. 1998. Role of root growth, arbuscular mycorrhiza and root exudates for the efficiency in nutrient acquisition. Field Crops Res. 56:203-207.

44) McEldowney, S., D.J. Hardman, and S. Waite. 1993. Treatment technologies. In S. McEldowney, J.D. Hardman, and S. Waite (ed.), Pollution Ecology and Biotreatment Technologies. Longman, Singapore Publishers, Singapore.

45) Montana State University Extension Services 2003. http://www.montana.edu/wwwpb/pubs/mt200312.html (accessed 08/01/2008).

46) Moreno-Peñarada, R., F. Lloret, and J.M. Alcañiz. 2004. Effect of sewage sludge on plant community composition in restored limestone quarries. Restor. Ecol. 12:290-296.

47) Nardi, S., G. Concheri, D. Pizzeghello, A. Sturaro, R. Rella, and G. Parvoli. 2000. Soil organic matter mobilization by root exudates. Chemosphere 41:653-658.

48) Oldeman, L.R. 1994. The global extent of soil degradation, pp. 99118. In Szabolcs, D.J. (ed.), Soil Resilience and Sustainable Land Use. CAB International, Wallingford.

49) Panesar, T.S., V.G. Marshall, and H.J. Barclay. 2001. Abundance and diversity of soil nematodes in chronosequences of coastal Douglas-fir forests on Vancouver Island, British Columbia. Pedobiologia 45:193212.

50) Pankhurst, C.E., B.M. Doube, and V.V.S.R. Gupta. 1997. Biological Indicators of Soil Health. CAB International, Wallingford.

51) Paul, E.A. 2005. Soil Biology and Biochemistry, 3rd edn. Academic Press, New York.

52) Pawluk, S. 1987. Faunal micromorphological features in moder humus of some western Canadian soils. Geoderma 40:3-16.

53) Peixoto, R.S., H.L.C. Coutinho, B. Madari, P.L.O.A. Machado, N.G. Rumjanek, J.D. Van Elsas, L. Seldin, and A.S. Rosado. 2006. Soil aggregation and bacterial community structure as affected by tillage and cover cropping in the Brazilian Cerrados. Soil Till. Res. 90:1628.

54) Phillips, I.R., M.G. Greenway, and S. Robertson. 2004. Use of phytocaps in remediation of closed landfills - correct selection of soil materials. Land Contamin. Reclam. 12:339-248.

55) Pickett, S.T.A. 1989. Space for time substitution as an alternative to long-term studies. In G.E. Likens (ed.), Long-term Studies in Ecology, pp. 110-135. Springer, New York.

56) Rao, P.S.C., G.B. Davis, and C.D. Johnston. 1996. Technologies for enhanced remediation of contaminated soils and aquifers: an overview, analysis, and case studies, p. 361-410. In R. Naidu, R.S. Kookana, D.P. Oliver, S. Rogers, and M.J. McLaughlin (ed.), Contaminants and the Soil Environment in the Australia Pacific Region. Kluwer Academic Publishers, London.

57) Rauser, W.E. 1990. Phytochelatins. Annu. Rev. Biochem. 59:61-86.

58) Robertson, G.P., D.C. Coleman, C.S. Bledsoe, and P. Sollins. 1999. Standard Soil Methods for Long-term Ecological Research. Oxford University Press, Oxford.

59) Rogerson, A., and J. Berger. 1981. Effect of crude oil and petroleumdegrading micro-organisms on the growth of freshwater and soil protozoa. J. Gen. Microbiol. 124:53-59.

60) Rogerson, A., W.Y. Shiu, G.L. Huang, D. Mackay, and J. Berger. 
1981. Determination and interpretation of hydrocarbon toxicity to ciliate protozoa. Aquat. Toxicol. 3:215-228.

61) Rokish, D.P., K.W. Dixon, K. Sivasithamparan, and K.A. Meney. 2000. Topsoil handling and storage effects on woodland restoration in western Australia. Restor. Ecol. 8:196-208.

62) Scheu, S., L. Reuss, and M. Bonkowski. 2005. Interactions between microorganisms and soil micro- and mesofauna, p. 253-275. In F. Buscot, and A. Varma (ed.), Microorganisms in Soils: Roles in Genesis and Functions. Springer, Berlin.

63) Schipper, L.A., B.P. Degens, G.P. Sparling, and L.C. Duncan. 2001. Changes in microbial heterotrophic diversity along five plant successional sequences. Soil Biol. Biochem. 33:2093-2103.

64) Singer, A.C., D.E. Crowley, and I.P. Thompson. 2003. Secondary plant metabolites in phytoremediation and biotransformation. Trends Biotechnol. 21:123-130.

65) Six, J., R.T. Conant, E.A. Paul, and K. Paustian. 2002. Stabilization mechanisms of soil organic matter: implications for $\mathrm{C}$ saturation of soils. Plant Soil 241:155-176.

66) Sôurková, M., J. Frouz, U. Fettweis, O. Bens, R.F. Hüttl, and H. Sântrucková. 2005. Soil development and properties of microbial biomass succession in reclaimed post mining sites near Sokolov (Czech Republic) and near Cottbus (Germany). Geoderma 129:73-80.

67) Stayley, J.T., R.P. Gunsalus, S. Lory, and J.J. Perry. 2007. Microbial Life, 2nd edn. Sinauer, Sunderland, Massachusetts.

68) Steffens, J.C. 1990. Heavy metal-binding peptides of plants. Annu. Rev. Plant Physiol. Plant Mol. Biol. 41:553-575.

69) Thomas, F., P. Folgarait, P. Lavelle, and J.P. Rossi. 2004. Soil macrofaunal communities along an abandoned rice field chronosequence in Northern Argentina. Appl. Soil Ecol. 27:23-29.
70) Tisdall, J.M., and J.M. Oades. 1982. Organic matter and water-stable aggregates in soils. J. Soil Sci. 33:141-163.

71) Van der Wall, A., J.A. van Veen, W. Smant, H.T.S. Boschler, J. Bloem, P. Kardol, W.H. van der Putten, and W. de Boer. 2006. Fungal biomass development in a chronosequence of land abandonment. Soil Biol. Biochem. 38:51-60.

72) Vécrin, M.P., and S. Muller. 2003. Top-soil translocation as a technique in the re-creation of species-rich meadows. Appl. Veget. Sci. 6:271-278.

73) Walker, T.S., H.P. Bais, E. Grotewold, and J.M. Vivanco. 2003. Root exudation and rhizosphere biology. Plant Physiol. 132:44-51.

74) Williamson, W.M., D.A. Wardle, and G.W. Yeates. 2005. Changes in soil microbial and nematode communities during ecosystem decline across a long-term chronosequence. Soil Biol. Biochem. 37:12891301.

75) Yao, H., D. Bowman, and W. Shi. 2006. Soil microbial community structure and diversity in a turfgrass chronosequence: land-use change versus turfgrass management. Appl. Soil Ecol. 34:209-218.

76) Ye, Z.H., J.W.C. Wong, M.H. Wong, A.J.M. Baker, W.S. Shu, and C.Y. Lan. 2000. Revegetation of $\mathrm{Pb} / \mathrm{Zn}$ mine tailings, Guangdong Province, China. Restor. Ecol. 8:87-92.

77) Young, T.P. 2000. Restoration ecology and conservation biology. Biol. Conserv. 92:73-83.

78) Zaitsev, A.S., M. Chauvat, A. Pflug, and V. Wolters. 2002. Oribatid mite diversity and community dynamics in a spruce chronosequence. Soil Biol. Biochem. 34:1919-1927.

79) Zheng, Z., and J.P. Obbard. 2003. Oxidation of polycyclic aromatic hydrocarbons by fungal isolates from an oil contaminated refinery soil. Environ. Sci. Pollut. Res. 10:173-176. 